\title{
PENGARUH LAMA PAPARAN SUHU KAMAR TERHADAP KUALITAS DNA PADA PEMERIKSAAN SWAB EARPHONE DALAM PENENTUAN JENIS KELAMIN
}

\author{
Aris Saputro ${ }^{1}$, Ahmad Yudianto $^{2}$, Toetik Koesbardiati ${ }^{3}$ \\ ${ }^{1,2,3}$ Program Studi S2 Ilmu Forensik Sekolah Pascasarjana Universitas Airlangga \\ Jln. Airangga 4-6 Surabaya. \\ ${ }^{2}$ Departemen Ilmu Kedokteran Forensik \& Medikolegal, FK Unair \\ ${ }^{3}$ Departemen Antropologi, FISIP Unair \\ Email : ${ }^{1}$ gan.droeng@gmail.com ; ${ }^{2}$ yudi4n6sby@yahoo.co.id : ${ }^{3}$ toek.unair@yahoo.com
}

\begin{abstract}
Abstrak
Metode identifikasi meliputi sidik jari, property, medis, gigi,dan analisis DNA. Spesimen yang banyak dipakai dalam pemeriksaan DNA dalam mengidentifikasi adalah spesimen yang terdapat bercak darah, bercak semen, vaginal swab, buccal swab dan tulang. Selain spesimen tersebut terdapat pula benda yang sering digunakan pelaku/korban terakhir kalinya. Misalnya alat Bantu dengar handphone (headset/earphone). Dalam penggunaannya earphone menempel pada kulit telinga bagian luar sehingga diduga adanya serumen yang menempel pada alat tersebut. Faktor-faktor yang dapat mempengaruhi kualitas DNA misal lama paparan. Sampai saat ini di Indonesia efek lama paparan suhu kamar terhadap kualitas DNA pada bahan DNA swab earphone melalui analisis DNA belum banyak diketahui. Jenis penelitian ini adalah observasional laboratoris. earphone yang telah digunakan sebelumnya kemudian terpapar suhu kamar dalam waktu 1, 7, 14 dan 20 hari. Dari hasil penelitian ini efek lingkungan yakni lama paparan dengan adanya penurunan kadar DNA, menunjukkan penurunan kadar cukup signifikan dari hari ke 1 sampai ke 20. Hanya pada sampel hari ke 1 yang masih menunjukkan terdeteksi pada lokus amelogenin $(X: 106 b p \& \quad Y: 112 \mathrm{bp}$ ) serta hari ke 7 hanya 1 buah sampel yang masih dapat terdeteksi. Dari hasil analisis dalam penelitian ini dapat disimpulkan sebagai berikut: terdapat pengaruh lama waktu paparan suhu kamar terhadap kualitas DNA dari bahan swab earphone. Penurunan kadar DNA swab earphone menunjukkan nilai signifikansi $(p<0.005)$ terhadap pengaruh lama waktu paparan suhu kamar.
\end{abstract}

Kata kunci : swab earphone, Kualitas DNA, Amelogenin

\begin{abstract}
Identification includes fingerprint, property, medical, dental and DNA assay methods. Specimens widely used in DNA assay for identification are blood spots/bloods, semen spots, vaginal swabs, buccal swabs and bones. In addition to these specimens, the last objects often used by the perpetrators/victims can be used for identification, such as hearing aids (headsets/earphones).

During their use, earphones are attached to the outer ear skin; thus, the earwax is suspected to adhere to the device. Length of exposure is among the factors that may affect the quality of DNA. Until recently in Indonesia, the effects of room temperature exposure duration on the quality of DNA found in earphone swabs through DNA analysis have not been widely known.

The present study was of laboratory observation. Earphones which have been used were subsequently exposed to room temperature for 1, 7, 14 and 20 days.

Results showed a significant decrease in DNA levels from day 1 to day 20. Only at day 1 that samples were detectable at the amelogenin locus (X: 106bp and Y: 112bp). Additionally, at day 7 only 1 sample was detectable. In conclusion, the length of room temperature exposure had a significant effect ( $p<0.005)$ on decreasing the quality of DNA found in earphone swabs.
\end{abstract}


Keywords: Earphone swabs, DNA quality, amelogenin

\section{PENDAHULUAN}

Identifikasi personal melalui analisis DNA merupakan alat diagnostik yang akurat dalam bidang forensik (Yudianto, 2010). Keunggulan dari analisis DNA adalah karena DNA memiliki kestabilan pada sel somatik yakni gambaran DNA dari darah, sperma, rambut, organ dan sebagainya identik, sehingga cocok untuk digunakan sebagai bahan identifikasi (Kirby, 1990).

Penentuan jenis kelamin melalui metode analisis DNA dalam pemeriksaannya menggunakan primer amelogenin. Amelogenin adalah sebuah gen yang mengkode protein yang terdapat pada kromosom seks (X dan $\mathrm{Y}$ ). Amelogenin diketahui relatif mudah digunakan untuk amplifikasi DNA walaupun sampel hanya menghasilkan jumlah DNA yang kecil atau DNA pada sampel yang sudah mengalami degradasi dengan cara menggunakan PCR dengan pengulangan 27 - 30 kali (Budowle et al, 1996; Yudianto, 2009).

Di tempat kejadian perkara akan didapatkan trace evidence biologi dan benda/alat yang sering digunakan pelaku atau korban terakhir kalinya. Satu diantaranya yakni alat Bantu dengar handphone yang sekarang sedang marak yakni headset atau earphone. Dalam penggunaannya earphone menempel pada kulit telinga bagian luar sehingga diduga adanya serumen yang menempel pada alat tersebut. Sebelumnya di Jepang telah dilakukan penelitian tentang hal tersebut, Seo Y, et al (2002) dalam penelitiannya melakukan identifikasi forensik melalui bahan serumen yang melekat pada earphone yang digunakan oleh pelaku kejahatan. Sosiawan (2004) dalam penelitiannya yakni melakukan analisis efektivitas swab serumen sebagai bahan alternative pemeriksaan DNA paternitas dan penelitian Yudianto (2015) yakni analisis DNA mitokondria swab earphone sebagai bahan alternatif identifikasi. Sehingga adanya earphone/headset disini mempunyai makna dalam identifikasi forensik.

Pada earphone yang sudah digunakan akan dapat ditemukan adanya serumen dari telinga bagian luar yang menempel/melekat penggunanya tersebut. Atas dasar tersebut dapat diperoleh kandungan DNAnya sehingga memungkinkan sebagai bahan pemeriksaan 
identifikasi forensik melalui analisis DNA (Seo Y, et al 2002).

Seringkali dalam proses pemeriksaan pada analisis DNA dihadapkan pada kondisi bahan atau spesimen pemeriksaan DNA yang tidak seperti diharapkan, contohnya spesimen tidak dalam kondisi segar atau fresh untuk dilakukan analisis DNA atau dikenal dengan istilah DNA degraded (degradasi DNA) ( Butler et al, 2003 ; Yudianto, 2010).

Kondisi spesimen mengalami degradasi DNA salah satunya akibat paparan suhu yang merupakan suatu kendala dalam analisis DNA. Paparan suhu merupakan salah satu faktor kerusakan DNA. Degradasi DNA pada jaringan lunak juga sering terjadi pada tubuh korban yang sudah rusak oleh karena pembusukan (Notosoehardjo, 1999). Kerusakan tersebut mengakibatkan kualitas DNA mengalami penurunan sehingga tidak bisa digunakan sebagai bahan pemeriksaan identifikasi.

Kadar DNA dari swab earphone yakni antara 20-300 $\mu \mathrm{g} / \mathrm{ml}$. Lama paparan suhu kamar $\left(28^{0} \mathrm{C}-31^{\circ} \mathrm{C}\right)$ yang masih menunjukkan deteksi positif pada DNA mitokondria yakni pada hari ke 1 (Yudianto, 2015). Dalam penelitian ini lama paparan yang digunakan sebagai patokan yakni hari ke 1 sampai hari ke 20 . Hari ke 1 dari penelitian sebelumnya oleh Yudianto (2015) yang masih menunjukkan JBP Vol. 17, No. 1, April 2015-Aris Saputro hasil deteksi positif sedangkan hari ke 7 merupakan waktu maksimal pemeriksaan olah TKP, kemudian hari ke 20 merupakan masa maksimal penahanan tersangka (KUHAP) serta hari ke 14 merupakan jarak tengah-tengah antara hari ke 7 sampai hari ke 20. Sejauh ini efek paparan suhu kamar terhadap kualitas DNA swab earphone untuk digunakan sebagai bahan identifikasi khususnya penentuan jenis kelamin melalui analisis DNA yang masih belum banyak diketahui.

Tujuan penelitian ini yakni Menganalisis pengaruh lama paparan terhadap kualitas DNA swab earphone untuk digunakan sebagai bahan identifikasi khususnya penentuan jenis kelamin melalui analisis DNA.

\section{METODOLOGI PENELITIAN}

Jenis Penelitian ini adalah observasional laboratories dengan rancangan penelitian time series. Sampel penelitian yakni DNA yang berasal dari swab earphone yang diambil dari responden di DOKKES POLDA JATIM dengan melalui uji kelaikan etik. Dari hasil perhitungan diketahui jumlah sampel yang diperlukan 56 responden.

\section{Tempat Penelitian : Human}

Genetic Study Group,Institute of Tropical Disease UNAIR.Kampus C Mulyorejo. Bahan Penelitian : swab earphone, bahan 
untuk ekstraksi DNA : DNAzol Reagent, Larutan $100 \%$ \& $70 \%$ ethanol. bahan untuk PCR : PCR Mix (12,5 ul) yang terdiri : dNTP (ATP,CTP,TTP GTP), $\mathrm{MgCl} 2$ dan Taq Polimerase, DW sigma (Nuclease Free water), primer amelogenin [X; 106bp \& Y; 112bp ] : 5'CTGATGGTTGGCCTCAAGCCTGTG 3' \& 5'TAAAGAGATTCATTAACTTGACTG $3^{\prime}$.

\section{HASIL PENELITIAN}

\subsection{Analisis pengaruh lama waktu paparan suhu kamar terhadap kadar DNA bahan swab earphone.}

Penelitian ini diawali dengan pemaparan sampel, yakni pemaparan suhu kamar pada earphone. Adapun suhu dan waktu paparan dalam penelitian ini berturut-turut: $29,5^{\circ} \mathrm{C}-30^{\circ} \mathrm{C}$; dalam waktu 1, 7, 14 dan 20 hari.

Kemudian dilanjutkan dengan ekstraksi DNA sampel dengan metode DNAzol. Hasil ekstraksi DNA sampel tersebut dilanjutkan dengan pengukuran kadar DNA dan kemurnian DNA sampel dengan menggunakan UV-Visible Spectrophotometer

Hasil pengukuran rerata pengukuran kadar DNA untuk sampel penelitian dapat dilihat di bawah ini.

Tabel 1. Kadar DNA hasil isolasi dari bahan swab earphone

\begin{tabular}{|l|c|}
\hline Sampel & $\begin{array}{c}\text { Rerata kadar } \\
(\mathbf{x} \pm \mathrm{SD})(\mu \mathrm{g} / \mathrm{ml})\end{array}$ \\
\hline
\end{tabular}

JBP Vol. 17, No. 1, April 2015-Aris Saputro

\begin{tabular}{|l|c|}
\hline Hari ke 0 & $1,5289 \pm 85,71$ \\
\hline Hari ke 1 & $11,19 \pm 5,58$ \\
\hline Hari ke 7 & $2,15 \pm 0,81$ \\
\hline Hari ke 14 & $0,93 \pm 0,79$ \\
\hline Hari ke 20 & $0,16 \pm 0,42$ \\
\hline
\end{tabular}

Keterangan :

$\mathrm{X}$

SD

Tabel 1 menunjukkan adanya penurunan rerata kadar DNA dari bahan swab earphone melalui paparan suhu kamar dalam rentang waktu 1, 7, 14 dan 20 hari. Dinyatakan bahwa semakin lama waktu paparan suhu kamar yang diberikan maka terjadi penurunan kadar DNA bahan swab earphone. Untuk memperjelas hal tersebut, maka di buat grafik penurunan kadar DNA bahan tulang berikut ini:

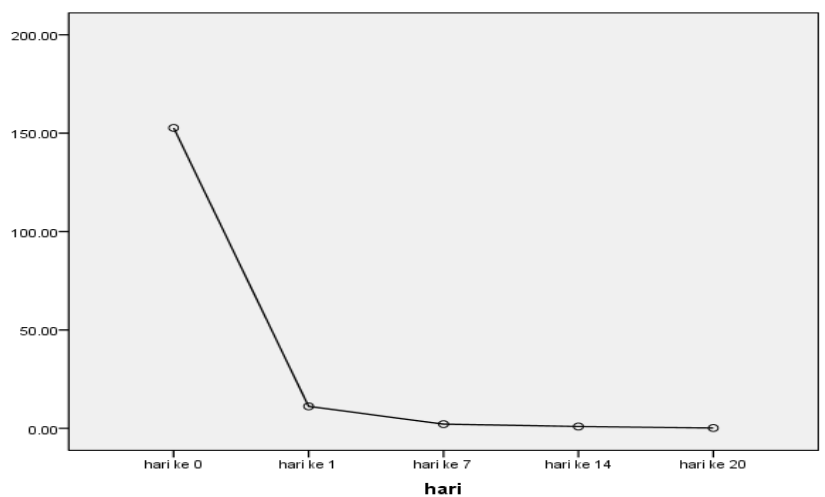

Gambar 1. Grafik : Pengaruh lama paparan terhadap kadar DNA swab earphone.

Untuk memastikan apakah terdapat pengaruh tersebut terhadap kadar DNA swab earphone maka dilakukan uji statistik. Menentukan pengaruh lama waktu paparan suhu kamar terhadap kadar DNA swab earphone, maka dilakukan pengujian normalitas (uji Kolmogorov Smirnov) untuk mengetahui distribusi dari sampel penelitian. 
Hasil menunjukkan kadar DNA swab earphone pada hari ke 1 dan hari ke 7 berdistribusi normal (Asymp.sig $(\mathrm{p})=0.952$ $\&$ 0.902, sig. p>0.05). Sedangkan pada hari ke 14 dan 20 tidak berdistribusi normal (Asymp.sig $(\mathrm{p})=0.410 \& 0.001$, sig. $\mathrm{p}>0.05$ ). Hasil homogenitas (Levene test) sampel dengan kadar DNA swab eraphone didapatkan tidak homogen $\{$ sig (p): kadar DNA: 0.000 , sig. homogen $\mathrm{p}>0,05)\}$, sehingga data kadar DNA swab earphone berdistribusi normal tetapi tidak homogen dan untuk melihat adanya pengaruh lama paparan suhu kamar terhadap kadar DNA digunakan uji Kruskall Wallis. Hasil uji tersebut menunjukkan terdapat pengaruh lama paparan suhu kamar terhadap penurunan kadar DNA swab earphone (sig.(p): 0.000, batas sig. $\mathrm{p}<0,05$ ). Untuk membandingkan kadar DNA pada masingmasing lama waktu paparan, mengingat kadar DNA sampel tidak homogen, maka digunakan uji t. $\quad \mathrm{jji} t$ tersebut membanding antara lama waktu paparan suhu kamar terhadap kadar DNA swab earphone. Hasil uji t pada data kadar DNA swab earphone diperoleh nilai yang didapat signifikansi: 0.002 , batas signifikansi $\mathrm{p}<0,05$.

\subsection{Analisis efek lama paparan suhu kamar pada DNA swab earphone dengan lokus amelogenin dalam penentuan jenis kelamin}

Untuk mengetahui efek lama paparan suhu kamar terhadap DNA swab earphone dengan pemeriksaan penentuan jenis kelamin melalui lokus amelogenin ( x: 106bp dan y: 112bp). Gambar berikut di bawah ini visualisasi hasil PCR lokus aemolegenin pada elektroforesis Polyacrylamid Agarose Composit Gel dalam sampel bahan swab earhone pada hari ke 1:

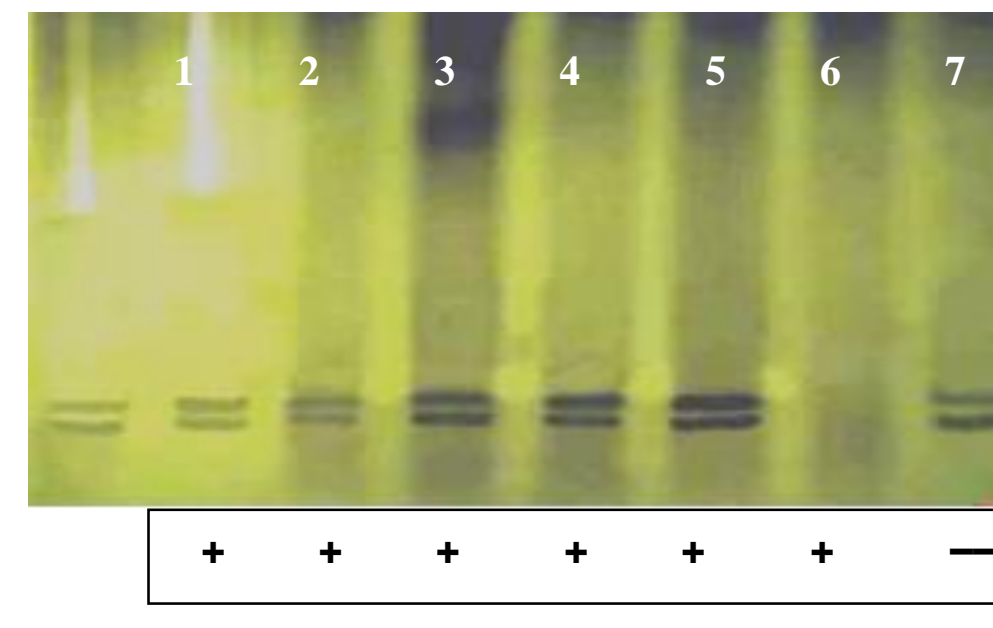

Gambar 2. Visualisasi hasil PCR lokus amelogenin bahan swab earphone .pada hari ke 1

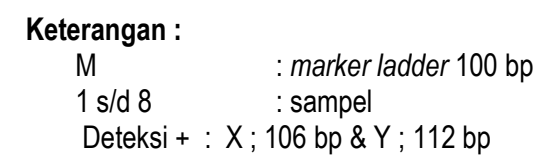

Visualisasi hasil PCR lokus amelogenin, gambar 2 diatas menunjukkan pada lama paparan suhu kamar hari ke 1 dari 8 buah sampel, 7 buah sampel masih dapat dideteksi (nampak band) yakni dua band (106bp \& 112bp) berjenis kelamin laki-laki. Selanjutnya i visualisasi hasil PCR lokus aemolegenin pada elektroforesis Polyacrylamid Agarose 
Composit Gel dalam sampel bahan swab earhone pada hari ke 7 :

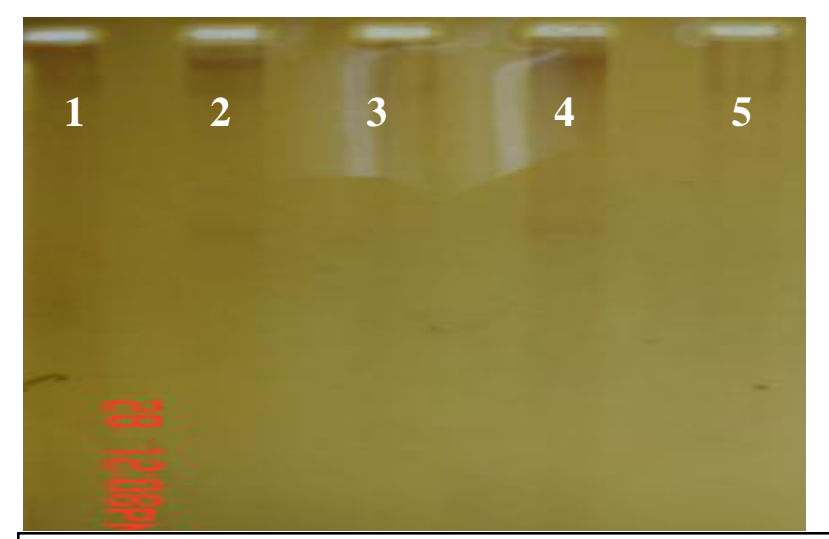

Gambar 3. Visualisasi hasil PCR lokus amelogenin bahan swab earphone .pada hari ke 7

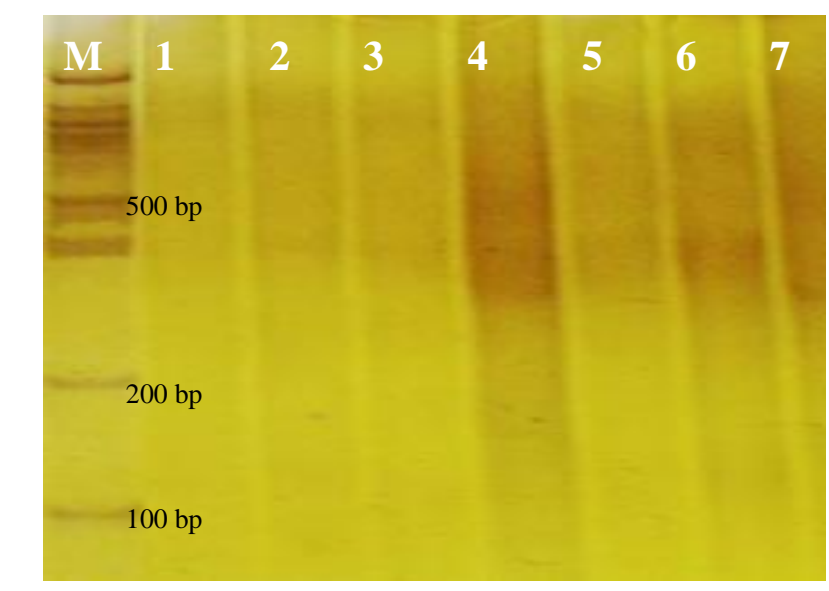

\section{DETEKSI -}

Gambar 4. Visualisasi hasil PCR lokus amelogenin bahan swab earphone .pada hari ke 14

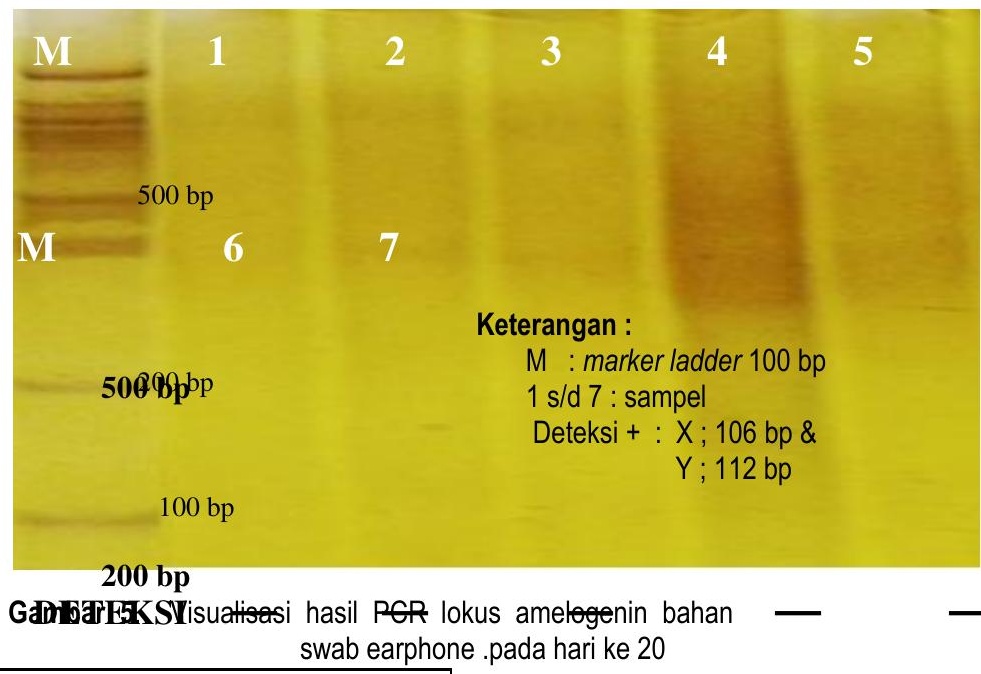

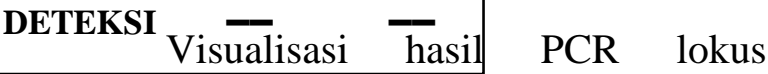
amelogenin, gambar 3,4,5 diatas menunjukkan pada lama paparan suhu kamar hari ke 7,14 dan 20 dari semua sampel sudah tidak dapat didketeranpartidak

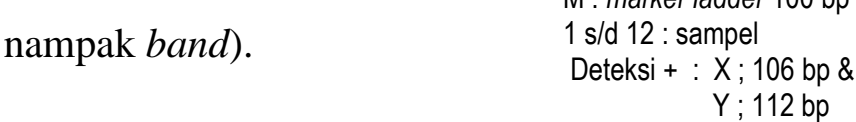

\section{PEMBAHASAN}

4.1 Analisis pengaruh lama waktu paparan suhu kamar terhadap kadar DNA bahan swab earphone.

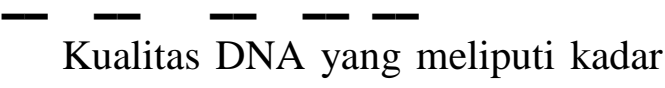

DNA dan kemurnian DNA. Kualitas DNA menjadi persyarat dalam pemeriksaan analisis DNA dengan metode Polymerase Chain Reaction (PCR). Kemurnian DNA yang digunakan yakni yang mempunyai nilai 1-2 (idea 1.8 - 2)(muladno, 2002).

Penelitian ini mendapatkan nilai kemurnian dalam range antara $0.00-1.80$ sehingga kemurnian DNA sudah mendapatkan nilai yang baik ( nilai 0.00 menunjukkan tidak adanya DNA dalam 
sampel tersebut). Sedangkan dari rerata kadar DNA pada penelitian ini mendapatkan 23,18 $\pm 57,58 \mathrm{ng} / \mu \mathrm{l}$, dimana nilai 0,00 menunjukkan tidak dapatkan adanya DNA dalam sampel.

Kadar DNA merupakan faktor penting dalam pemeriksaan analisis DNA terutama terhadap keberhasilan amplifikasi pada sampel-sampel DNA. Penurunan kadar DNA ingá 1 ng berpotensi terhadap penurunan kemampuan deteksi STR hinggá 95\% (Butler, 2003). Integritas DNA merupakan sebuah hal yang utama bagi pemeriksaan DNA forensik. Hal ini mengandung pengertian bahwa meski pemeriksan kadar DNA yang diperoleh relatif tinggi, namun bila DNA telah mengalami fragmentasi atau degradasi (fragmented or degraded DNA), maka kadar DNA yang tinggi, menjadi sebuah hal yang kurang berarti.

Jumlah kadar DNA yang dibutuhkan dalam analisis DNA berbedabeda tergantung dari kebutuhan dan jenis pemeriksaan. Pada pemeriksaan Short Tandem repeat (STR) hanya membutuhkan konsntrasi DNA minimal antara $1-25 \mathrm{ng}$. Selain tergantung dari kadar DNA juga dibutuhkan kualitas DNA yang mencukupi yaitu DNA yang digunakan harus dalam kondisi terdegradasi seminimal mungkin (Butler, 2003). Apabila DNA mengalami kondisi terdegradasi parah, maka JBP Vol. 17, No. 1, April 2015-Aris Saputro mengakibatkan primer tidak dapat menempel pada DNA target yang akan digandakan (Muladno, 2002).

Degradasi DNA dapat disebabkan oleh 2 faktor, yaitu faktor endogenous dan eksogenous. Sedangkan faktor endogenous berasal pada sel sendiri, yang dikenal sebagai kerusakan spontan. Faktor eksogenous berasal dari lingkungan. Faktor eksogenous dari lingkungan seperti halnya kelembaban, temperature lingkungan sangatlah berpengaruh terhadap kondisi DNA serta faktor-faktor lainnya yakni adanya bahan kontaminan yakni bakteri. Jaringan yang terdegradasi oleh bakteri dapat terjadi autolisis dan depurinasi spontan (Gollenberg et al, 1996; Burger et al, 1999). Paparan abnormal dari bahanbahan kimia, $\mathrm{pH}$, temperatur, maupun paparan lainnya dapat menyebabkan DNA mengalami kerusakan (damage) pula (Farley et al, 1991; Melcher, 2000).

Hasil pemeriksaan pengukuran kadar DNA dalam penelitian ini menunjukkan adanya kecenderungan penurunan kadar DNAnya pada bahan swab earphone terhadap lama waktu paparan suhu kamar. Untuk memastikan seberapa jauh pengaruh lama waktu paparan suhu kamar terhadap kadar DNA dalam sampel penelitian ini maka dilakukan beberapa uji statistik 
Hasil uji statistik dengan uji Kruskall Wallis dan uji t terhadap kadar DNA swab earphone menunjukkan secara rerata terdapat pengaruh yang bermakna terhadap lama waktu paparan suhu kamar. Hasil uji Kruskall Wallis tersebut menunjukkan terdapat pengaruh lama paparan suhu kamar terhadap penurunan kadar DNA swab earphone (nilai yang didapat signifikansi: 0.000 , batas signifikansi $\quad \mathrm{p}<0,05)$ Untuk membandingkan kadar DNA pada masingmasing lama waktu paparan, mengingat kadar DNA sampel tidak homogen, maka digunakan uji t. Uji $t$ tersebut membanding antara lama waktu paparan suhu kamar terhadap kadar DNA swab earphone. Hasil uji t pada data kadar DNA swab earphone diperoleh nilai yang didapat signifikansi: 0.002, batas signifikansi $\mathrm{p}<0,05$. Dengan demikian perbedaan kadar DNA secara bermakna pada semua lama waktu paparan, sehingga dengan kata lain hipotesis yang menyebutkan ada pengaruh lama waktu paparan suhu kamar terhadap kualitas DNA swab earphone diterima.

Dapat dinyatakan, umumnya semakin lama waktu yang dipaparkan suhu kamar pada bahan swab earphone maka terjadi penurunan kadar DNA bahan swab earphone tersebut. Waktu lama paparan pada suhu kamar tersebut menyebabkan JBP Vol. 17, No. 1, April 2015-Aris Saputro ikatan konjugasi mengalami kerusakan dan basa nitrogen lepas sehingga DNA terfragmentasi bahkan rusak.

Kadar DNA merupakan faktor penting dalam pemeriksaan DNA forensik yakni berpengaruh terhadap keberhasilan STR genotyping pada sampel-sampel DNA khususnya pada pemeriksaan identifikasi melalui analisis DNA.

\subsection{Analisis efek lama paparan suhu kamar pada DNA swab earphone dengan lokus amelogenin dalam penentuan jenis kelamin}

Visualisasi hasil Polymerase Chian Reaction (PCR) dianalisis secara deskriptif, yakni dengan melihat ada tidaknya gambaran band atau pita sesuai dengan ukuran produk PCR (base pair) yakni lokus amelogenin ( $\mathrm{X}:$ 106bp \& Y: 112bp). Dalam penelitian ini menunjukkan pada paparan suhu kamar hari ke 0 dan ke 1 yang masih dapat dideteksi (nampak band/pita) melalui lokus amelogenin. Sedangkan pada paparan suhu kamar hari ke 7, 14 dan 20 menunjukkan tidak dapat terdeteksi (tidak nampak band/pita).

Ketidak dideteksinya visualisasi hasil PCR pada sampel-sampel tersebut diakibatkan oleh karena kualitas DNAnya. Kualitas DNA mencakup yakni kadar DNA, kemurnian DNA dan kondisi DNA ( degradasi ). Pada pemeriksaan melalui analisis DNA dengan metode PCR, dibutuhkan kualitas DNA yang mencukupi. 
Keberhasilan PCR menurut Yuwono (2006) sangat tergantung oleh beberapa faktor, yaitu: deoksiribonukleotida triphosphat (dNTP), oligonukleotida primer, DNA cetakan, larutan buffer, siklus reaksi, enzim yang digunakan dan faktor teknis dan non teknis lainnya, misal kontaminasi.

Yang dimaksud kualitas DNA yang mencukupi yakni DNA yang digunakan harus dalam analisis DNA dalam kondisi baik dan apabila terdegradasi maka degradasi ini harus seminimal mungkin. Jika DNA dalam kondisi terdegradasi parah mengakibatkan primer tidak dapat menempel atau anealling pada DNA target yang akan digandakan, sehingga kualitas DNA yang bagus menjadi prasyarat fundamental bagi keberhasilan reaksi PCR secara keseluruhan. Menurut Chung (2004) sensitivitas PCR merupakan fungsi dari jumlah siklus dan kadar serta integritas dari DNA.

Jika DNA mengalami degradasi parah mengakibatkan primer tidak dapat menempel atau annealing pada DNA target yang akan digandakan (Muladno, 2002; Rudin et al, 2002; Yuwono, 2006). Menurut Muladno (2002), untuk mendapatkan hasil visualisasi yang adekuat dibutuhkan kemurnian DNA yang adekuat dan kadar DNA yang memadai, sehingga DNA dapat digunakan sebagai JBP Vol. 17, No. 1, April 2015-Aris Saputro bahan pemeriksaan DNA termasuk dalam hal ini adalah identifikasi dan tes paternitas.

Degradasi DNA pada faktor eksogenous dibagi menjadi 2 tipe (Chen L, et al, 2000 ; Yudianto, 2006) : Tipe I : DNA terdegradasi karena faktor waktu yang relatif lama, dimana kerusakan DNA yang tejadi seringkali disebabkan proses kimia dan biasanya proses ini berlangsung lamban. Tipe II : DNA terdegradasi yang cepat, hal ini disebabkan faktor kelembaban, sinar matahari bahkan suhu ekstrim tinggi

Degradasi DNA ini merupakan salah satu penyebab kegagalan deteksi DNA pada pemeriksaan analisis DNA dengan metode PCR dalam penelitian ini. Hal tersebut sesuai dengan yang dikemukan oleh Bartlett \& Stirling (2003) dan Yudianto (2010), mengenai beberapa kemungkinan yang menyebabkan kegagalan deteksi DNA antara lain: jumlah DNA target yang minimal, degradasi DNA sehingga primer tidak dapat menempel, kurangnya DNA polymerase dan siklus PCR serta adanya inhibitor PCR.

Siklus PCR bisa dikendalikan dengan dilakukannya optimasi sebelumnya, tetapi tidak menutup kemungkinan terjadi kegagalan pada amplifikasi DNA. Diduga hal ini karena adanya inbitor PCR yakni bahan 
dekalsifikasi yaitu EDTA. Disamping itu kemungkinan kurang mencukupi ataupun berlebihnya $\mathrm{Mg}^{2+}$, DNA Polymerase dan siklus PCR yang digunakan kurang relevan untuk diduga sebagai penyebab terjadinya kegagalan dari proses amplifikasi. Kegagalan proses amplifikasi ditandai dengan tidak adanya band pada hasil elektroforesis. Hal ini bisa diantisipasi dengan penggunaan PCR master mix, yang memiliki kandungan $\mathrm{Mg}^{2+}$, DNA taq Polymerase, dNTP dalam jumlah yang disesuaikan dengan kebutuhan reaksi PCR optimal dan telah terbukti memiliki kehandalan dalam dalam reaksi PCR saat ini (Promega, 2004), sedangkan siklus yang kurang mencukupi pada reaksi PCR, sudah diantisipasi dengan melakukan optimasi PCR pada primer-primer yang digunakan (Yudianto,2010).

Ketidakcukupan DNA polimerase serta siklus PCR, faktor-faktor ini bisa dikendalikan dalam kegagalan deteksi yakni dengan penggunaan PCR master mix. PCR master mix memiliki kandungan $\mathrm{Mg}^{2+}$, DNA tag polimerase, dNTP dalam jumlah yang disesuaikan dengan kebutuhan reaksi yang optimal. Konsentrasi $\mathrm{Mg}^{2+}$ yakni sekitar 1,5-4 mM, kelebihan konsentrasi $\mathrm{Mg}^{2+}$ menyebabkan terjadinya non specific reaction dengan adanya smear pada elektroforesis, sebaliknya bila $\mathrm{Mg}^{2+}$ tidak cukup JBP Vol. 17, No. 1, April 2015-Aris Saputro menyebabkan no amplified product atau tidak ada pita/band pada hasil elektroforesis.

Sedangkan jumlah enzim taq polimerase bila berlebihan terjadi gambaran pada elektroforesis bentukan smear (non specific reaction), sebaliknya bila tak mencukupi (kurang) maka efisiensi amplifikasi terganggu dan memberi gambaran tidak ada pita. Pada faktor inhibitor PCR yakni berupa EDTA yang digunakan dalam proses dekalsifikasi sampel, penyulit ini dapat dihindari yakni dalam penggunaan ethanol sebagai presipitasi dalam ekstraksi/isolasi DNA. Ethanol merupakan bahan yang potensial memisahkan DNA dengan komponen lainnya saat ekstraksi DNA berlangsung (Schiffner, 2005)(Yudianto, 2010).

Beberapa hasil dalam penelitian ini menunjukkan kegagalan deteksi berupa kegagalan amplifikasi DNA dengan PCR. Kegagalan ini dapat disebabkan degradasi atau damage DNA akibat efek lama waktu paparan suhu kamar tersebut. Serumen yang menempel pada earphone tersebut mengandung sel epitel liang telinga luar yang terlepas, dimana sel epitel tersebut tidak ada perlindungan sehingga langsung terpapar dari faktor-faktor eksternal yang menyebabkan degradasi DNA lebih cepat.

$$
\text { Menurut Melcher (2000), }
$$

kerusakan DNA dari luar yang disebabkan 
oleh paparan-paparan contohnya sinar-X, chemical agents, spontaneous instability, ataupun oleh temperatur yang sangat tinggi (temperatur ekstrim) akan mengakibatkan adanya banyak tipe kerusakan, contohnya kerusakan rantai (strand) DNA (baik double strand maupun single strand), base damage (kerusakan basa DNA), sugar damage, bahkan terjadinya DNA-DNA crosslinks maupun DNA-protein crosslinks. Faktor lingkungan tersebut menyebabkani DNA mengalami degradasi atau degraded DNA. Degradasi ini bisa cepat atau lambat, tergantung faktor yang mempengaruhi dan waktu terjadinya paparan.

Pada penelitian ini didapatkan bahan: swab earphone yang masih bisa digunakan sebagai bahan analisis DNA dalam pemeriksaan jenis kelamin (lokus amelogenin $\mathrm{X}: 106 \mathrm{bp} \& \mathrm{Y}: 112 \mathrm{bp}$ ) terhadap paparan suhu kamar $\left(28^{0} \mathrm{C}\right.$ $31^{\circ} \mathrm{C}$ ) yakni maksimal pada hari ke 1.

Sehingga dari kajian temuan dalam penelitian ini diharapkan dapat diaplikasikan dalam identifikasi sehingga dapat dipertimbangkan dalam mempercepat proses identifikasi terutama pada kejadian bencana (mass disaster) maupun kasus-kasus kriminal lainnya. Terutama pada Tempat kejadian perkara (TKP) yang sedikit trace evidencenya.

\section{KESIMPULAN}

Dari hasil analisis dalam penelitian ini dapat disimpulkan sebagai berikut : Terdapat pengaruh lama waktu paparan suhu kamar terhadap kualitas DNA dari bahan swab earphone Penurunan kadar DNA swab earphone menunjukkan nilai signifikansi $(\mathrm{p}<0.005)$ terhadap pengaruh lama waktu paparan suhu kamar. Deteksi visualisasi hasil PCR lokus amelogenin yang menunjukkan hasil deteksi positif (+) hanya pada paparan pada hari ke 0 dan ke 1 (satu) sedangkan pada hari ke 7, 14,20 tidak terdeteksi.

\section{DAFTAR PUSTAKA}

Affoed, RL., and Caskey, CT., 1994. DNA analysis in Forensic disease and animal identification, Curr. Opin. Biotech.5:29-32

Atmaja, DS., 2005. Peranan Sidik jari DNA dalam Bidang Forensik: Seminar Nasional Aplikasi DNA Finger Printing dalam Bidang Kedokteran, 29 Agustus 2005, Yogyakarta: Program Studi Bioteknologi UGM

Butler, JM., 2001. STR Analysis for human testing,STR Typing, Current protocols in Human Genetic Unit, Vol.14, No.8, pp 1-37

Butler, JM., 2003. Forensic DNA Typing. San Diego - Florida: Academic Press, page 28-30, page 59-96.

Davis, LG., Mark, D. Dibner., James, F.Battey., 1986. Basic Methodes in Molecular Biology, New York: Elsevier 
Gibson, J., 2003. Modern Physiology and Anatomy For Nurses, $1^{\text {st }}$ ed, Oxford: Published by Arrangement with Blackwell Science Limited, page 238-239

Henry A.E., 1992. PCR Technology, Principles and Applications for DNA Amplification, New York: W.H.Freeman and Company

Houk, MH., 2001. Mute Witnesses Trace Evidence Analysis, Tokyo: Academic Press, page 87-117

Idries, A.M., 1997. Pedoman Ilmu Kedokteran Forensik, 1 ed, Jakarta: Penerbit Binarupa Aksara

Jackson, M Kelly., 1990. The Polymerase Chain Reaction, Simposium DNA Probing, Teknik dan Penerapan Klinis, HKKI

Jusuf, M., 2001. GENETIKA I Struktur \& Ekspresi Gen, Jakarta: Sagung Seto

Mark, A.F., 1991. Forensik DNA Technology, Lewis Publishers inc.

Murray et al., 1997. Biokimia Harper, edisi 24, EGC, hal 366-370

Muladno., 2002. Seputar tehnologi rekayasa genetik, Edisi I, Bogor: Pustaka

Nidom C.A.,2005. Teknik Biomolekuler untuk Penentuan 'DNA Profil',Kumpulan makalah seminar sehari tentang Tes Paternitas ditinjau dari berbagai aspek, TDC UNAIR, November 2005.

Notosoehardjo I., 1999. Penentuan jenis kelamin berdasarkan Pemeriksaan DNA dan
Antropometri tulang, Disertasi Doktor, Unair, Surabaya.

Notosoehardjo I., 2001. DNA Forensics; Paternity test, Past, Present, and Future,J.For.Scien,VIII,pp 34-45.

Notosoehardjo I., Kuntaman., 2002. Teori dasar dan penerapan Praktis $P C R$, TDC Universitas Airlangga, hal 1-11.

Sosiawan A., 2004. Analisis Efektivitas swab serumen sebagai bahan alternatif pemeriksaan DNA paternitas, Medical Research Unit FK Unair

Syukriani Y., 2012. DNA Forensik, Jakarta: PT Sagung

Terry, M \& Kimberlyn, N., 2003. The case of degraded DNA: mtDNA ancient analysis to the rescue, Mitotyping Technologies, LLC, State Coll. PA

Watson et.al., 1986. Molecular Biology of The Gene, 4nd.Ed. Cummings Publishing Company,Inc.

Westwood SA \& Werret DJ., 1990. An evaluation of the Polymerase Chain Reaction method for forensic application, Elsevier Science International, pp 201215.

Watson D. J.et al., 1988. DNA Rekombinan, Penerbit Erlangga

William G.E., 1992. Introduction Forensic Science, 2 ed, CRC Press Boca Rotan Florida, page 232-259.

Yasuhisa Seo., Taketo Uchiyama., Hirokazu Matsuda., Kenshi Shimizu., Yasunari Takami., Tasuo Nakayama., Keiichi Takhama,, 2002. Mitochondrial DNA and STR Typing of Matter 
Jurnal Biosains Pascasarjana Vol. 17 (2015) pp

(C) (2015) Program Pascasarjana Universitas Airlangga, Indonesia

adhering to an earphone, Jour of Forensic Sci; 47(3):605-608.

Yudianto A., 2009. Sex determinant melalui pemeriksaan DNA rambut manusia, Medical research unit, FK Unair.

Yudianto., 2010. Analisis DNA Tulang dan gigi pada lokus Short Tandem Repeat-Combined DNA Index System (STRCODIS),Y-Chromosome STRs \& Mitochondrial DNA (mtDNA)Akibat efek paparan panas suhu tinggi. Disertasi,
Program Pascasarjana,

Universitas Airlangga

Yudianto A., Sispitasari YE., Margaret N., 2015. Analisis DNA mitokondria swab earphone sebagai bahan alternative pemeriksaan identifikasi forensic, Penelitian Unggulan Sekolah Pascsarjana Universitas Airlangga

Zainuddin, M., 2000. Metodologi Penelitian, Kumpulan kuliah Pascasarjana, Universitas Airlangga 